\title{
Seasonal Plasticity of Peripheral Auditory Frequency Sensitivity
}

\author{
Joseph A. Sisneros and Andrew H. Bass \\ Department of Neurobiology and Behavior, Cornell University, Ithaca, New York 14853
}

Female midshipman fish (Porichthys notatus) use the auditory sense to detect and locate vocalizing males during the breeding season. Detection of conspecific vocal signals is essential to their reproductive success and can evoke strong phonotactic responses in gravid females but not in spent females that have released all of their eggs. Here, we test the hypothesis that seasonal variation in reproductive state affects the neurophysiological response properties of the peripheral auditory system in female midshipman fish. Iso-intensity responses of eighth nerve afferents from the sacculus, the main auditory end organ of the inner ear, to individual tones were measured for spike rate and vector strength (VS) of synchronization. Most auditory saccular units in reproductive, summer females showed robust temporal encoding up to $340 \mathrm{~Hz}$, whereas nonreproductive winter females showed comparable encoding only up to $100 \mathrm{~Hz}$. The dramatic upward shift in temporal encoding among summer fish was paralleled by increases in best frequency (BF), maximum evoked spike rate at $\mathrm{BF}$, VS values at BF, and the percentage of units that showed significant VS to iso-intensity tones $>140 \mathrm{~Hz}$. Reproductive summer females were best suited to encode the higher harmonic components of male advertisement calls. This first demonstration of a natural cyclicity in peripheral auditory frequency sensitivity among vertebrates may represent, in this case, an adaptive plasticity of the female midshipman's auditory system to enhance the acquisition of auditory information needed for mate identification and localization during the breeding season.

Key words: auditory plasticity; hearing; sacculus; reproduction; hair cell; vocalization

\section{Introduction}

Although a number of studies have focused on morphological correlates of seasonal or reproductive state-dependent changes in the adult vertebrate nervous system, fewer have considered its possible concurrent neurophysiological plasticity. Where available, physiological studies have focused mainly on the neuroendocrine axis, for example changes in the electrical excitability of gonadotropin-releasing hormone-containing neurons (for review, see Kelly and Wagner, 1999). Although psychoacoustic studies of humans suggest that reproductive state affects female auditory sensitivity and sound localization (for review, see McFadden, 1998) (also see Haggard and Gaston, 1978; Swanson and Dengerink, 1988; Altermus et al., 1989), supporting neurophysiological evidence is lacking. Seasonal plasticity in vocal-acoustic behavior is well known among nonmammalian vertebrates, although studies of the neuronal correlates of reproductive periodicity have focused mainly on the anatomical traits of vocal motor systems (for review, see Tramontin and Brenowitz, 2000; Ball et al., 2002). By necessity, reproductive periodicity in the operation of any species' vocal behavior may be accompanied by changes in the ability of the auditory system to detect and process changing

Received Aug. 5, 2002; revised Nov. 6, 2002; accepted Nov. 12, 2002.

This research was supported by a National Institutes of Health (NIH)/National Institute of Deafness and Other Communication Disorders (NIDCD) postdoctoral fellowship (1F32DC00445) to J.A.S. and an NIH/NIDCD grant (DC00092) to A.H.B. We thank P. Forlano, M. Marchaterre, J. McKibben, J. Lee, Captain Lee Bradford, and the crew of RV John Martin for field assistance, G. Cailliet, H. Lohr, M. Kaanapu, and the Moss Landing Marine Laboratory for logistical support, B. Land, P. Wrege, K. Reeve, M. Marchaterre, D. Bodnar, M. Weeg, J. McKibben, J. O'Sullivan, and M. Ezcurra for technical advice and assistance, and M. Weeg, B. Land, and two anonymous reviewers for helpful comments on this manuscript.

Correspondence should be addressed to Dr. Joseph A. Sisneros, Department of Neurobiology and Behavior, Cornell University, Seeley G. Mudd Hall, Ithaca, NY 14853. E-mail: jas226@cornell.edu.

Copyright $\odot 2003$ Society for Neuroscience $\quad 0270-6474 / 03 / 231049-10 \$ 15.00 / 0$ vocal parameters. Here, we consider seasonal neurophysiological plasticity in the frequency sensitivity of the peripheral auditory system of a seasonally breeding vertebrate for which vocal communication is essential to its reproductive success.

The auditory system of the plainfin midshipman fish, Porichthys notatus, provides an excellent model for investigating seasonal changes in the reception, processing, and production of vocal signals (for review, see Bass, 1996; Bass et al., 1999). Vocal signals are essential to the successful reproduction of this nocturnally active species, which migrates during the late spring and summer from deep offshore sites into the intertidal zone to spawn in nests positioned under rocky shelters. Nesting males produce long duration ( $>1 \mathrm{~min}$ ) multiharmonic advertisement calls, or "hums," to attract females to their nests (Bass et al., 1999). The fundamental frequency $(90-100 \mathrm{~Hz})$ of the hum is highly stable, with several prominent harmonics ranging up to $400 \mathrm{~Hz}$ that typically contain as much or more spectral energy as the fundamental. Reproductively active females use the auditory sense to detect and locate humming conspecific males. After depositing their eggs in a humming male's nest, females leave the breeding grounds and return to deep waters (Brantley and Bass, 1994). Underwater acoustic playbacks of natural and synthetic hums evoke strong phonotactic responses in gravid females but not in spent females that have released most of their eggs (McKibben and Bass, 1998, 2001a), suggesting that reproductive state may influence the response properties of the auditory system.

Here, we test the hypothesis that seasonal variation in reproductive state can modulate the neurophysiological response properties of the peripheral auditory system in female midshipman fish. We show that in a wild population of midshipman fish 
the discharge properties and frequency response dynamics of auditory saccular afferent neurons change with female reproductive state. We propose that this plasticity is an adaptive response by the female's auditory sense to enhance mate detection and localization during the breeding season.

\section{Materials and Methods}

Experimental animals. Midshipman fish ( $P$. notatus) have three known adult reproductive morphs that include females and two male morphs: types I and II (Bass, 1996). Type I males acoustically court females and provide parental care for fertilized eggs, whereas an alternative type II male morph shows neither of these behaviors and instead sneak or satellite spawns to steal fertilizations from the type I males. Adult female midshipman (10.0-18.4 cm standard length) were collected during the years 1999-2002 both in the nonreproductive "winter" season (late September to early April) and in the reproductive summer season (June to August). In the winter, nonreproductive females with regressed ovaries that contained only small $(<1 \mathrm{~mm}$ diameter) unyolked eggs were collected by trawl at a depth of 70-120 m in Monterey Bay near Moss Landing, CA. Animals rapidly adjusted to the sudden change in water depth and showed no visible signs of stress in captivity. In the summer, gravid, reproductively active females with ovaries that contained relatively large (5 mm diameter) yolked eggs (Brantley and Bass, 1994) were collected by hand from the nests of parental (type I) males at low tide from a natural breeding population near the northern end of Tomales Bay, CA, in the same geographical location used in many previous studies of this species (Bass, 1996; Bass et al., 1999). Female midshipman were maintained in saltwater aquaria at $12-15^{\circ} \mathrm{C}$ and fed a diet of brine shrimp or goldfish, or both, every 3-4 d. Neurophysiology experiments were performed on female fish within $15 \mathrm{~d}$ after collection from trawls or nests. Additional experiments were also performed on females maintained in captivity after collection from nests for 26-32 d during the summer and 2-6 months during the winter. The former group had ovaries that contained both reduced yolked eggs $(<5 \mathrm{~mm}$ diameter $)$ and small unyolked eggs ( $<1 \mathrm{~mm}$ diameter), whereas the latter group showed regressed ovaries that contained only small unyolked eggs like those observed in females collected during the winter. All experimental procedures followed National Institutes of Health guidelines for the care and use of animals and were approved by the Cornell University Institutional Animal Care and Use Committee.

Neurophysiology experiments. Recording methods followed those used previously to characterize eighth nerve afferents in midshipman fish (McKibben and Bass, 1999, 2001b). Midshipman were anesthetized in a solution of $0.2 \%$ benzocaine and then given an intramuscular injection of pancuronium bromide $(\sim 0.5 \mathrm{mg} / \mathrm{kg})$ and fentanyl $(\sim 1 \mathrm{mg} / \mathrm{kg})$ for immobilization and analgesia, respectively. Primary afferents of the saccule, which is the main auditory end organ in this species (Cohen and Winn, 1967; McKibben and Bass, 1999, 2001b), were then exposed by a dorsal craniotomy. The cranial cavity was filled with Fluroinert (3M, Rochester, MN) to enhance clarity and prevent drying. A dam of denture adhesive cream $\sim 2 \mathrm{~cm}$ high was built up around the cranial cavity, which allowed the animal to be lowered below the water surface. Animals were positioned $\sim 10 \mathrm{~cm}$ above an underwater loudspeaker embedded in sand on the bottom of a $30 \mathrm{~cm}$ diameter, $24 \mathrm{~cm}$ high Nalgene experimental tank [design as in Fay (1990)]. The tank rested on a pneumatic vibration isolation table inside an acoustic isolation chamber (Industrial Acoustics, New York, NY), and all recording and stimulus generation equipment were located outside the chamber. Animals were perfused continuously with fresh seawater at $14-15^{\circ} \mathrm{C}$ through the mouth and over the gills during all neurophysiology experiments. Extracellular single unit discharges were recorded from saccular afferent neurons with glass microelectrodes filled with $4 \mathrm{M} \mathrm{NaCl}(\sim 20-40 \mathrm{M} \Omega)$. Auditory neurons were randomly sampled from eighth nerve afferents that innervated the saccular otolith and amplified using standard electrophysiology techniques. Single units were identified with a search stimulus (a single tone from 70 to $100 \mathrm{~Hz}$ ) as the microelectrode was advanced through the nerve. Ana$\log$ unit discharges were amplified (Getting $5 \mathrm{~A}$ ), filtered at $150-5000 \mathrm{~Hz}$ (Stanford Research Systems SR650), and then recorded on a Macintosh
Centris computer running under a custom synthesis and data acquisition software control program (CASSIE, developed by J. Vrieslander, Cornell University). A pattern-matching algorithm in CASSIE was used to extract visually identified single units during the extracellular recordings. On isolation of single units, the iso-intensity responses were measured for both synchronization and spike rate (see data analysis). The best frequency $(\mathrm{BF})$ of a unit was determined as the frequency that evoked the maximum spike rate above the resting discharge rate or the highest vector strength of synchronization (VS) to the individual tones, or both. Auditory threshold was determined at BF and was designated as the lowest stimulus intensity that evoked a significant VS value and produced an increase in spike rate.

Stimulus generation. Acoustic stimuli were synthesized with the CASSIE software running on a Macintosh Centris with a 12-bit DA board (MacAdios). Stimuli were attenuated (Tucker Davis programmable attenuator), amplified (NAD stereo amplifier $3020 \mathrm{~A}$ ), and played through an underwater loudspeaker (UW-30 University Sound). The frequency response of the underwater speaker was measured with a minihydrophone (Bruel and Kjaer 4130) in the position normally occupied by the fish's head. Relative sound pressure measurements were then made with a spectrum analyzer (Stanford Research Systems SR780), calibrated by peak-to-peak voltage measurements on an oscilloscope, and then adjusted with CASSIE software so that the sound pressure at all used frequencies $(60-800 \mathrm{~Hz})$ was of equal amplitude within $\pm 1 \mathrm{~dB}$. Measurements of pressure differences between various points in our experimental tank were made in previous studies to confirm that the primary axis of particle motion was in the vertical plane orthogonal to the surface of the underwater speaker (McKibben and Bass, 1999) and that reflections from the tank walls and water surface did not alter the sound pressure waveform of the acoustic signals (Bodnar and Bass, 1997, 1999). Recent evidence indicates that many primary afferents that innervate the midshipman saccular otolith respond to dorsoventral acceleration and that the iso-intensity curves based on pressure are similar in shape to isointensity curves based on particle motion or displacement (Weeg et al., 2002).

Basic auditory stimuli consisted of eight repetitions of single tones 500 $\mathrm{msec}$ in duration with fall and rise times of $50 \mathrm{msec}$. Each repetition was presented at a rate of one every $1.5 \mathrm{sec}$. To measure the iso-intensity

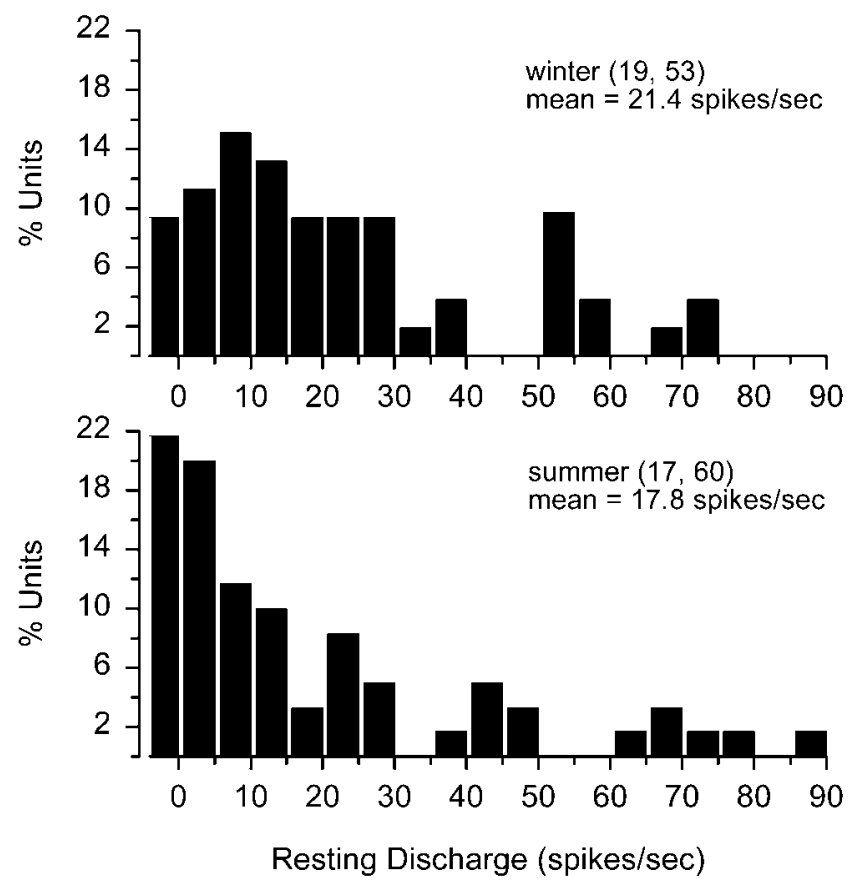

Figure 1. Resting discharge rate histograms of auditory saccular afferent neurons recorded from adult female midshipman fish ( $P$. notatus) during the winter and summer. The numbers of animals and auditory saccular afferent neurons tested are indicated in parentheses. 


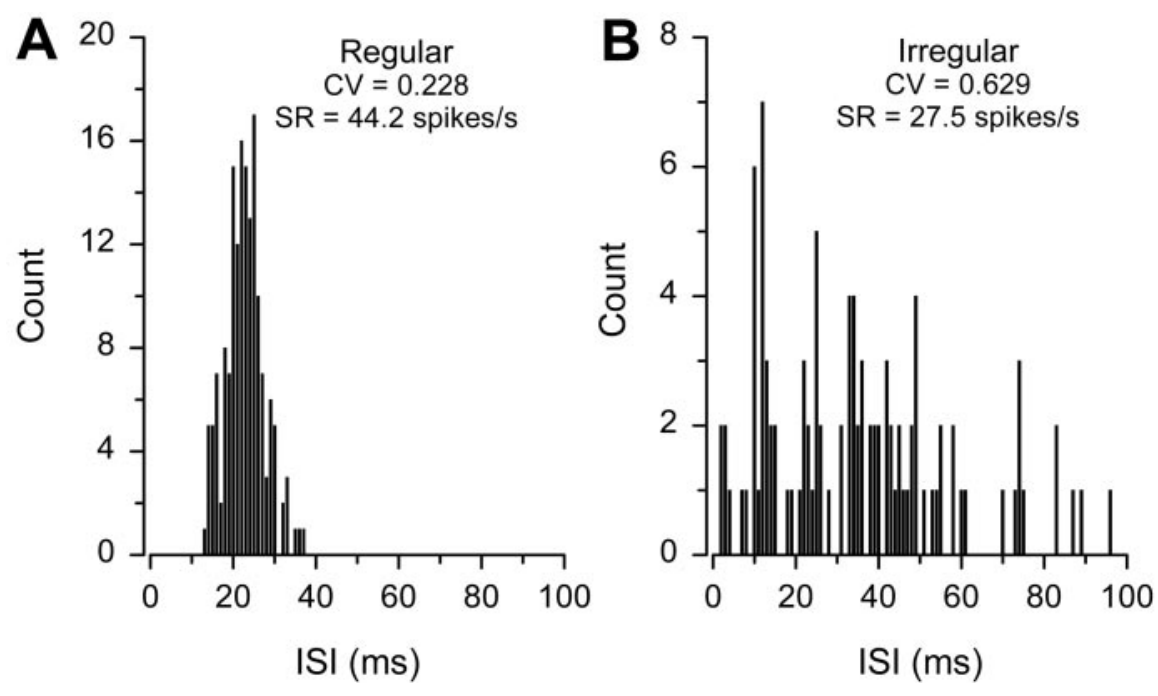

Figure 2. Resting discharge patterns of auditory saccular afferent neurons recorded from female midshipman. Representative ISI distributions are shown for both regular and irregular resting discharge patterns. Discharge variability is expressed as the coefficient of variation $(C V)$, a dimensionless ratio of SD to mean ISI duration. SR, Spike rate. Bin width $=1 \mathrm{msec}$.

responses, pure tones were presented at 10 or $20 \mathrm{~Hz}$ increments between 60 and $400 \mathrm{~Hz}$ at a sound pressure of $130 \mathrm{~dB}$ re $1 \mu \mathrm{Pa}$. This sound level is consistent with known levels for midshipman sounds recorded near the nest (Bass and Clark, 2003).

Data analysis. Resting discharge rates were measured for eight repetitions of the stimulus interval with no stimulus present and then used to generate interspike interval (ISI) histograms with $1 \mathrm{msec}$ bins. Units with resting discharge activity were classified as either regular or irregular units on the basis of their ISI histograms such that units with ISIs that were normally distributed ( $\chi^{2}$ test for goodness of fit; $p>0.05$ ) were classified as regular units and those that were not normally distributed were classified as irregular units. Resting discharge variability was expressed as the coefficient of variation (CV), the ratio of SD to mean ISI duration. Spike train responses to individual tones were quantified for both maximum evoked average spike rate and VS, which is a description of the temporal pattern of firing (i.e., phase locking). Spike rates were averaged across the repetitions over the entire stimulus duration. VS, calculated from the spike train data acquired over the entire stimulus duration, measures the degree of phase locking to a periodic signal and varies from zero for a uniform or random distribution to 1 if all spikes fall in the same bin. VS is equivalent to the mean vector length for the circular distribution of spikes over the period of the stimulus and was calculated according to Goldberg and Brown (1969) using 2 msec bins. A Rayleigh $Z$ test was used to test whether synchronization to pure tones was significantly different from random $(p<0.05)$ (Batschelet 1981). Only significant VS values were used to generate iso-intensity curves. Although iso-intensity responses for both average evoked spike rate and VS of synchronization were collected for auditory saccular afferents, measurements of VS were less variable than evoked spike rate in this and previous studies (McKibben and Bass, 1999, 2001b), and thus VS was a more consistent measure for frequency encoding in midshipman fish. In general, phase-locking accuracy (i.e., VS of synchronization) rather than spike rate responsiveness is a better predictor of frequency encoding among teleost fishes (Fay 1978a, 1982, 1994) and among vertebrates in general for frequencies of $\leq 1 \mathrm{kHz}$ (Javel and Mott, 1988).

Statistical analysis. Seasonal differences (nonreproductive winter vs reproductive summer) in resting discharge rate, $\mathrm{BF}$, and threshold at $\mathrm{BF}$ were determined by a Student's $t$ test. In cases in which data sets failed tests of normal distribution or equal variance and a $t$ test could not be used, data were analyzed using the nonparametric Mann-Whitney $U$ test. For all tests, $\alpha$ was set at 0.05 . An analysis of the slopes for the relationship of VS at BF and resting discharge rate between winter and summer females was determined by an analysis of covariance (ANCOVA). Associations between CV and ISI and VS at BF and resting discharge rate were determined using Pearson's correlation and linear regression. A $\chi^{2}$ analysis of a $2 \times 3$ contingency table was used to determine differences in the relative numbers of resting discharge types (silent, regular, and irregular units) between winter and summer seasons. The effects of season (nonreproductive winter vs reproductive summer) and resting discharge type (silent, regular, and irregular units) on VS at BF and resting discharge rate were determined by a two-way ANOVA followed by the Tukey test for planned pairwise multiple comparisons.

\section{Results \\ Resting discharge activity}

Of the 172 primary auditory neurons isolated in this study, resting discharge activity was recorded without any auditory stimulation from 113 units in 36 adult female fish (19 in winter and 17 in summer). Because there was no difference in the resting discharge rates between captive winter females $(\overline{\mathrm{x}}=20.6 \pm 18.6 \mathrm{SD}$ spikes/sec; $n=7$ animals, 25 units) and wild-caught winter females $(\overline{\mathrm{x}}=22.1 \pm 20.8 \mathrm{SD}$ spikes/sec; $n=$ 12 ; 28 units) ( $t$ test, $t=-0.26$; df $=51 ; p=0.80$ ), data were pooled and then compared with summer females recorded within $15 \mathrm{~d}$ after collection from nests. Resting discharge rates ranged from 0 to 70.8 spikes/sec for winter females and 0 to 87.4 spikes/sec for summer females (Fig. 1). Three general resting discharge patterns were observed in both winter and summer females: silent, regular, and irregular. This resting discharge classification scheme is similar to that used by McKibben and Bass (1999), with the exception that the irregular class in this study includes units that were classified previously as variable, bursting, and irregular units in McKibben and Bass (1999). The classification scheme used in this study more closely follows that used in previous studies of both fish and tetrapods (Fay, 1978b; Köppl and Manley, 1990; Manley et al., 1991), thereby facilitating comparisons.

Silent units, by definition, did not display any resting discharge activity, whereas units that displayed regular and irregular discharge patterns were best observed when plotted as ISI histograms (Fig. 2). Regular units had ISIs that were normally distributed, relatively constant, and had ISI histograms with a single pronounced peak (Fig. 2A). Regular units had CVs that ranged in the winter from 0.163 to $0.477(\overline{\mathrm{x}}=0.343 \pm 0.100 \mathrm{SD} ; n=8$ animals; 9 units $)$ and in the summer from 0.249 to $0.419(\overline{\mathrm{x}}=$ $0.307 \pm 0.079 \mathrm{SD} ; n=3 ; 3$ units). In contrast, irregular units had ISIs that were not distributed normally but were highly variable and scattered without any obvious periodicity (Fig. 2 B). Irregular units had CVs that ranged in winter from 0.416 to $1.385(\overline{\mathrm{x}}=$ $0.741 \pm 0.235 \mathrm{SD} ; n=19 ; 39$ units) and in summer from 0.304 to $1.228(\overline{\mathrm{x}}=0.732 \pm 0.219 \mathrm{SD} ; n=14 ; 44$ units $)$. Mean CV for regular and irregular units did not differ between winter and summer (two-way ANOVA; effect of season; $F=0.08$; $\mathrm{df}=1,91$; $p=0.77$ ), but the mean $\mathrm{CV}$ of irregular units was approximately twice that of the regular units (two-way ANOVA; effect of resting discharge type; $F=28.62 ; \mathrm{df}=1,91 ; p<0.001)$. There was no relationship between $\mathrm{CV}$ and mean ISI for regular and irregular units $[r=-0.04$; null hypothesis (Ho): $\beta=0 ; t=-0.44 ; p=$ $0.66]$.

Of the three general types of resting discharge patterns, irreg- 
Table 1. Discharge characteristics of auditory saccular afferent neurons from winter and summer female midshipman, $P$. notatus

\begin{tabular}{llcl}
\hline Season & Type & $\begin{array}{l}\text { RD rate } \bar{x} \pm \text { SD } \\
(\text { spikes/sec) }\end{array}$ & VS at BF $\bar{x} \pm$ SD \\
\hline Winter & Silent $(n=5)$ & $0 \pm 0$ & $0.99 \pm 0.01$ \\
$N=19$ & Irregular $(n=39)$ & $24.7 \pm 19.6$ & $0.83 \pm 0.11$ \\
& Regular $(n=9)$ & $16.5 \pm 10.9$ & $0.75 \pm 0.19$ \\
Summer & Silent $(n=13)$ & $0 \pm 0$ & $0.92 \pm 0.13$ \\
$N=17$ & Irregular $(n=44)$ & $22.1 \pm 23.1$ & $0.89 \pm 0.10$ \\
& Regular $(n=3)$ & $31.7 \pm 26.3$ & $0.74 \pm 0.05$ \\
\hline
\end{tabular}

ular discharge activity was the most common discharge pattern observed in both winter (74\%) and summer (73\%) females followed by silent $($ winter $=9 \%$, summer $=22 \%$ ) and regular $($ winter $=17 \%$, summer $=5 \%)$. The relative numbers of resting discharge types differed between winter and summer seasons (contingency table; $\chi^{2}=7.74 ; \mathrm{df}=2 ; p<0.05$ ) such that summer females had more silent units (13\% increase) and fewer regular units (12\% decrease) than winter females.

Mean resting discharge rate did not differ between females in the winter $(\overline{\mathrm{x}}=21.4 \pm 19.8$ SD spikes/sec; $n=19 ; 53$ units $)$ and in the summer $(\overline{\mathrm{x}}=17.8 \pm 22.7 \mathrm{SD}$ spikes/sec; $n=17 ; 60$ units $)$ (two-way ANOVA; effect of season; $F=0.53$; $\mathrm{df}=1,107 ; p=$ 0.47). Resting discharge rates also did not differ between regular and irregular units, both of which were naturally higher than the rates of silent units (Table 1) (two-way ANOVA and Tukey test; effect of resting discharge type; $F=8.83 ; \mathrm{df}=2,107 ; p<0.005$ ).

Plasticity of frequency response and sensitivity to auditory stimuli

Responses to single tone stimuli at $130 \mathrm{~dB}$ re $1 \mu \mathrm{Pa}$ were recorded for 172 auditory saccular primary afferent neurons in 42 adult female midshipman (24 winter and 18 summer fish). Isointensity responses measured for both spike synchronization and spike rate revealed differences in the shape of the iso-intensity curves and BF of auditory saccular afferents between summer and winter fish. Figure 3 shows representative responses to isointensity tones of $130 \mathrm{~dB}$ (re $1 \mu \mathrm{Pa}$ ) for individual auditory saccular afferents based on both vector strength of synchronization (filled circles) and maximum evoked spike rate (open squares). The frequency that evoked the highest VS and highest spike rate above resting discharge rate was defined as the BF. The isointensity curves of winter females generally consisted of profiles with BFs from 60 to $200 \mathrm{~Hz}$; VS and spike rate values declined rapidly above $\mathrm{BF}$ to their lowest values at $380-400 \mathrm{~Hz}$ (Fig. 3A$C)$. In contrast, the iso-intensity curves of summer females generally consisted of profiles with a broader range of BFs extending up to $280 \mathrm{~Hz}$; VS values declined gradually above BF, whereas spike rate declined rapidly above $\mathrm{BF}$ (Fig. $3 D-F$ ).

Because the mean BF did not differ between wild-caught winter females (sampled $\leq 15 \mathrm{~d}$ after trawl collection) and those held in winter captivity 2-6 months after collection from nests ( $t$ test; $t=0.67 ; \mathrm{df}=86 ; p=0.50)$, data were pooled and then used for comparison with data from summer females (sampled $\leq 15 \mathrm{~d}$ after collection from nests). On the basis of vector strength of synchronization, most of the BFs (83\%) for winter females were $60-100 \mathrm{~Hz}$, whereas for summer females only $48 \%$ of the units had BFs in this range, with the majority (52\%) shifted upward from 120 to $280 \mathrm{~Hz}$ (Fig. $4 A, B$ ). Median BF was higher in the summer $(140 \mathrm{~Hz})$ than winter $(70 \mathrm{~Hz})$ (Mann-Whitney $U$ test; $Z=-3.90 ; \mathrm{df}=170 ; p<0.001)$. In addition, VS at BF was also higher in the summer $(\overline{\mathrm{x}}=0.87 \pm 0.11 \mathrm{SD} ; n=18$ animals; 84 units) than during the winter $(\overline{\mathrm{x}}=0.81 \pm 0.14 \mathrm{SD} ; n=24 ; 88$ units) ( $t$ test; $t=-2.87$;f $=170 ; p<0.005$ ). Likewise, maxi-
A

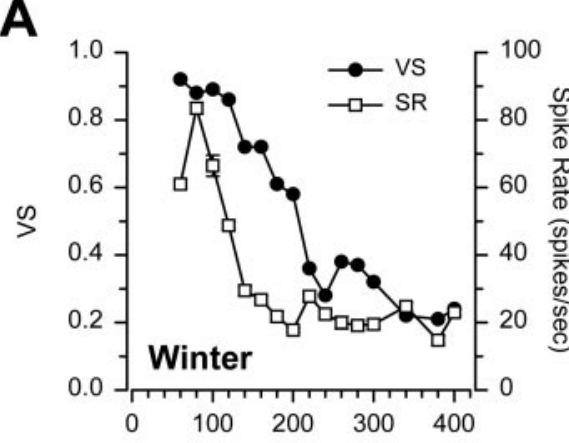

D

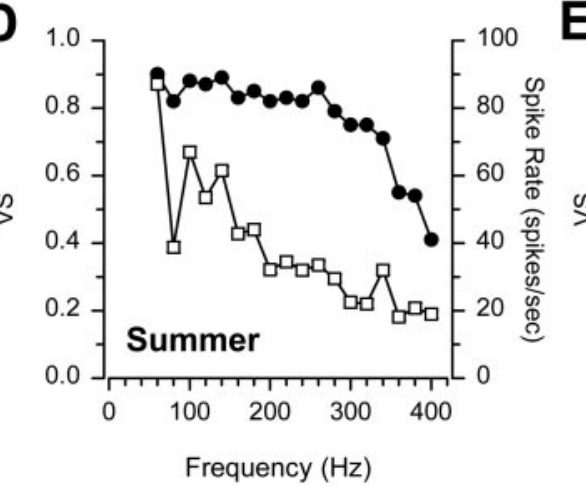

B

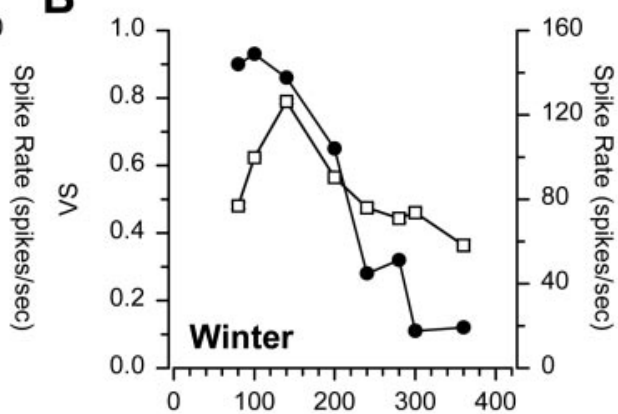

E

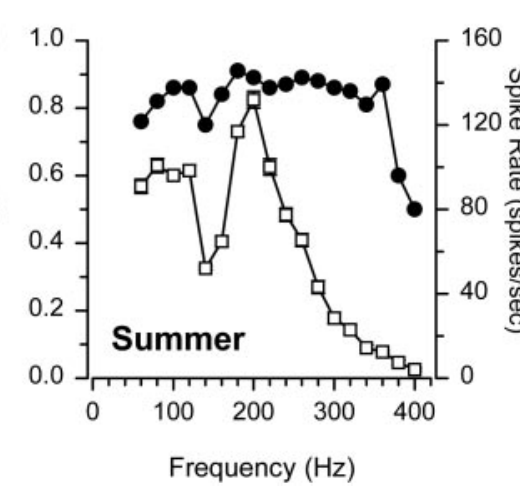

C
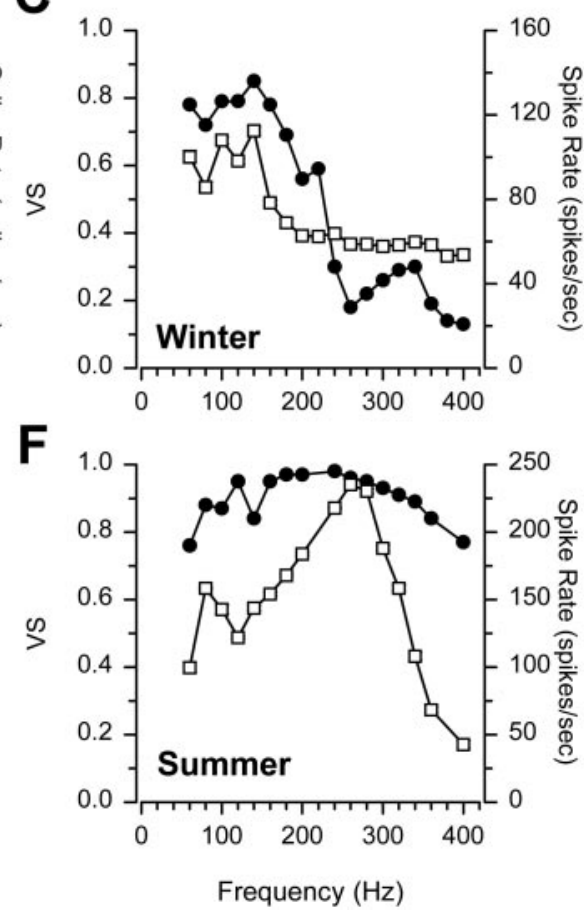

Figure 3. Representative examples of iso-intensity curves of individual auditory saccular afferents of female midshipman in response to single tones at $130 \mathrm{~dB}$ (re $1 \mu \mathrm{Pa}$ ) during the winter (top row) and summer (bottom row). Iso-intensity responses are plotted for vector strength of synchronization (VS, $O$ ) and maximum evoked spike rate (SR, $\square$ ) at each frequency tested for each saccular afferent. All SR data are plotted as mean \pm 1 SD. Note that most of the SD bars are obscured by symbols. These iso-intensity curves have BFs that span the range of BFs for winter and summer fish. Resting discharge rate corresponding to each unit is as follows: $A, 21.0$ spikes/sec; $B, 70.4 \mathrm{spikes} / \mathrm{sec} ; C, 59.0 \mathrm{spikes} / \mathrm{sec} ; D, 15.4 \mathrm{spikes} / \mathrm{sec} ; E, 2.8 \mathrm{spikes} / \mathrm{sec} ; F, 64.8 \mathrm{spikes} / \mathrm{sec}$. 

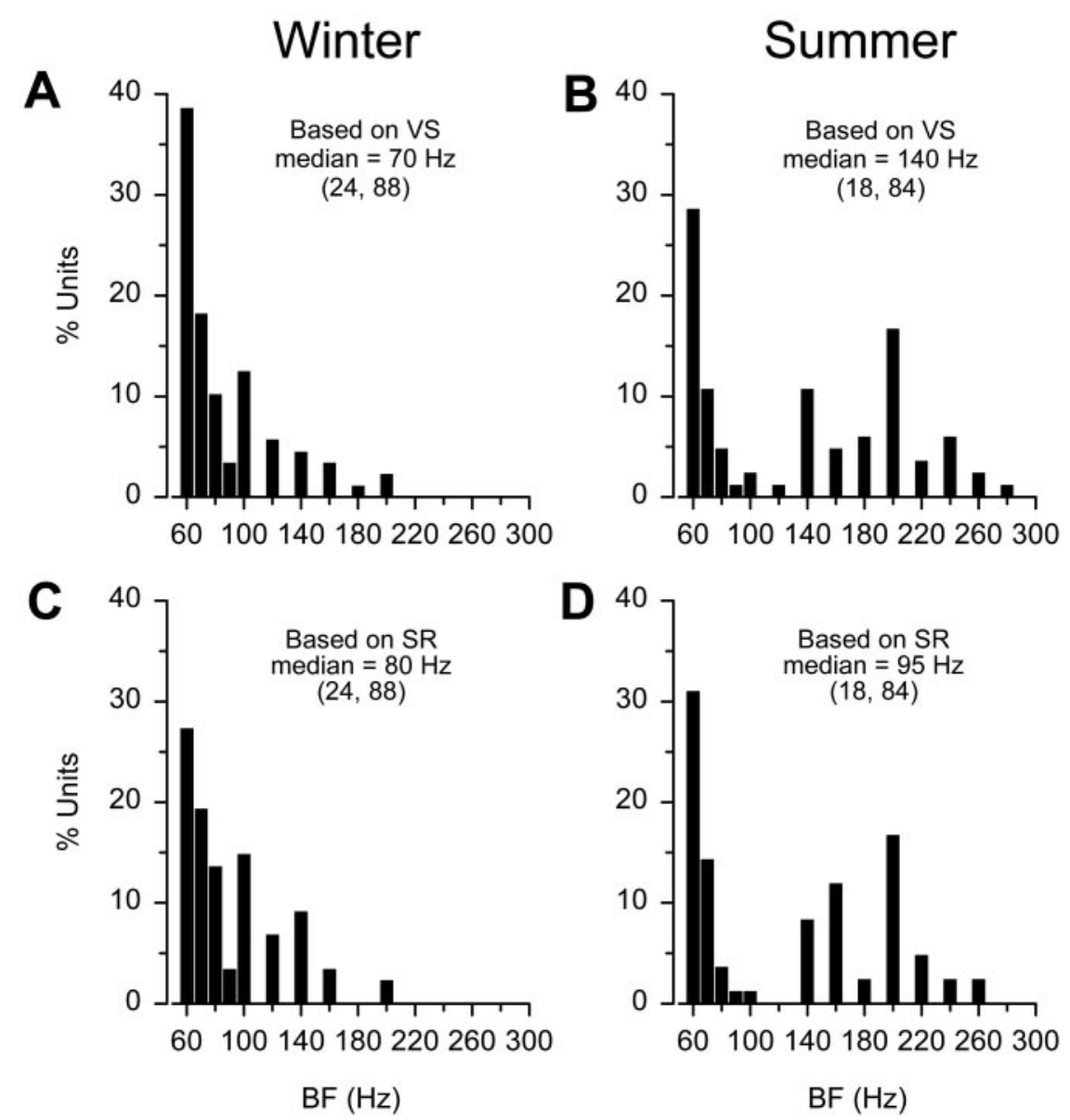

Figure 4. Best frequency histograms of auditory saccular afferent neurons recorded from a wild population of female midshipman. Adult females were collected during the nonreproductive winter (left column) and reproductive summer (right column) seasons. $A, B$, Distribution of best frequencies $(B F)$ for auditory saccular afferents of winter $(A)$ and summer $(B)$ females based on the vector strength (VS) of synchronization to iso-intensity tones of $130 \mathrm{~dB}$ (re $1 \mu \mathrm{Pa}$ ). Note that median $\mathrm{BF}$ is twofold greater for summer females than winter females. $C, D, B$ F histograms for winter $(C)$ and summer $(D)$ females based on maximum evoked spike rate $(S R)$ to iso-intensity tones of $130 \mathrm{~dB}$ (re $1 \mu \mathrm{Pa}$ ). Note that median $\mathrm{BF}$ is also higher for summer females than winter females. The numbers of animals and auditory saccular afferent neurons tested are indicated in parentheses.

mum evoked spike rate (peak minus resting discharge) at BF was higher in the summer $(\overline{\mathrm{x}}=37.9 \pm 37.2$ SD spikes/sec; $n=18 ; 84$ units $)$ than in the winter $(\overline{\mathrm{x}}=25.7+25.3$ SD spikes/sec; $n=24$; 86 units) (Mann-Whitney $U$ test; $Z=-2.12$; df $=168 ; p<0.05$ ), and median $\mathrm{BF}$ based on maximum evoked spike rate was also higher in summer $(95 \mathrm{~Hz})$ than winter $(80 \mathrm{~Hz})$ (Mann-Whitney $U$ test; $Z=-2.35$; $\mathrm{df}=168 ; p<0.05)$. Most of the BFs $(78 \%)$ based on spike rate for winter females were from 60 to $100 \mathrm{~Hz}$, whereas for summer females only $51 \%$ of the units had BFs in this range, with $49 \%$ shifted upward from 120 to $260 \mathrm{~Hz}$ (Fig. 4C,D). In sum, these results show that BFs and the measures for temporal encoding (VS and maximum evoked spike rate at BF) are higher in the reproductive summer than in the nonreproductive winter.

Differences in the iso-intensity response profiles between winter and summer females were best observed when the median and quartile VS values were plotted for the entire population of auditory primary afferents (Fig. 5). As noted earlier (Materials and Methods), VS rather than spike rate responsiveness is a more accurate measure of frequency encoding among teleost fishes, including midshipman. Thus, only the iso-intensity curves based on VS of synchronization were used to compare differences in the response profiles for the entire population of auditory saccular afferents of summer and winter fish. During the winter, median VS declined gradually from 0.77 to 0.40 between 60 and $360 \mathrm{~Hz}$ (Fig. 5A). In sharp contrast, median VS remained relatively high $(\geq 0.70)$ between 60 and $340 \mathrm{~Hz}$ and then gradually declined to 0.46 at $400 \mathrm{~Hz}$ during the summer (Fig. 5B). Among winter females, there was a precipitous drop in the number of units showing significant VS values (Rayleigh $Z$ test; $p>0.05$ ) above $140 \mathrm{~Hz}$. The percentage of units with significant VS declined from $91 \%$ at $140 \mathrm{~Hz}$ to $44 \%$ at $340 \mathrm{~Hz}$ in winter females (Fig. $5 C$ ), whereas the percentage of units with significant VS declined only from 96 to $75 \%$ over the same range of frequencies in summer females (Fig. 5D). Thus, the upward shift in robust temporal encoding among summer females was paralleled by an upward shift in the percentage of units that showed significant VS values above $140 \mathrm{~Hz}$.

Auditory threshold at BF was determined for 22 saccular primary afferents from 15 adult female midshipman (7 winter, 8 summer fish). There was no difference in the threshold at BF (Fig. 6) between females in the winter $(\overline{\mathrm{x}}=104 \pm 6$ $\mathrm{SD} \mathrm{dB}$ re $1 \mu \mathrm{Pa} ; n=7$ animals; 11 units) and summer $(\overline{\mathrm{x}}=103 \pm 6 \mathrm{SD} \mathrm{dB}$ re 1 $\mu \mathrm{Pa} ; n=8 ; 11$ units) $(t$ test; $t=0.20 ; \mathrm{df}=$ $20 ; p=0.84)$. However, the median BF at the determined threshold for this subsample of 22 auditory afferents was 2.25fold greater for summer females $(160 \mathrm{~Hz})$ than winter females $(70 \mathrm{~Hz})$ (MannWhitney $U$ test; $Z=-3.77$; df $=1,22$; $p<0.001)$. Thus, auditory threshold did not change between reproductive seasons, but the BF at auditory threshold for saccular primary afferents was greater during the breeding summer than the nonbreeding winter months.

Saccular afferents from summer females began to show a decrease in the encoding of frequencies $>300 \mathrm{~Hz}$ and $\mathrm{BF}$ when sampled $>25 \mathrm{~d}$ after their collection from a nest. Iso-intensity responses of saccular afferents were measured for spike synchronization and evoked spike rate from a limited sample of four adult summer females recorded 26-32 d after collection from their nests. On the basis of VS, $100 \%$ of the BFs for summer females sampled $>25 \mathrm{~d}$ after nest collection were $60-100 \mathrm{~Hz}$ compared with only $48 \%$ of the BFs for summer females sampled $<15 \mathrm{~d}$ after nest collection (Fig. 7A). Median BF was lower in summer females sampled $>25 \mathrm{~d}$ after nest collection (median $=$ $70 \mathrm{~Hz} ; n=4$ animals; 10 units) than in summer females sampled at $<15 \mathrm{~d}$ (median $=140 \mathrm{~Hz} ; n=18 ; 84$ units) (Mann-Whitney $U$ test; $Z=-2.09$; df $=92 ; p<0.05$ ). However, there was no difference in median BF on the basis of maximum evoked spike rate between summer females sampled at $>25 \mathrm{~d}$ (median $=65$ $\mathrm{Hz} ; n=4 ; 10$ units) and $<15 \mathrm{~d}$ (median $=95 \mathrm{~Hz} ; n=18 ; 84$ units) (Mann-Whitney $U$ test; $Z=-1.85$; $\mathrm{df}=92 ; p=0.06$ ). Median VS values remained relatively high $(>0.70)$ between 60 and $300 \mathrm{~Hz}$ for summer females sampled at both $>25$ and $\leq 15 \mathrm{~d}$ 
after nest collection, but declined much more rapidly between 300 and $400 \mathrm{~Hz}$ for the $>25$ d group than the $\leq 15$ d group (Fig. $7 B$ ). Thus, the BF and more generally the encoding of auditory frequencies $>300 \mathrm{~Hz}$ begins to decrease after $25 \mathrm{~d}$ from the collection of the nest.

\section{Relationship between VS at BF and resting discharge rate}

A weak but significant linear relationship was identified between phase-locking accuracy at $\mathrm{BF}$ and resting discharge rate for a subsample of auditory units that were analyzed for both resting discharge rate and VS at BF. VS of synchronization at BF was negatively correlated with resting discharge rate for females in both the winter $(r=-0.48$; Ho: $\beta=0$; $t=-3.95 ; p<0.001)$ and the summer $(r=-0.47$; Ho: $\beta=0 ; t=-4.08$; $p<0.001)$. Because the slopes of these regression lines did not differ between winter and summer females (ANCOVA; $F=0.835$; $\mathrm{df}=1,109 ; p=0.36)$, the data were pooled, and a linear relationship between VS at BF and resting discharge rate was plotted (Fig. 8) $(r=-0.48$; Ho: $\beta=0$; $t=-5.72$; $p<$ $0.001)$. In addition, an analysis of phaselocking accuracy at BF on the basis of resting discharge type (silent, regular, and irregular units) revealed that mean VS at BF for each resting discharge type did not differ between winter and summer (two-way ANOVA; effect of season; $F=0.04$; $\mathrm{df}=1,107 ; p=$ $0.84)$. However, there was a significant difference in mean VS at BF among the resting discharge types such that mean VS at BF was highest for silent units, intermediate for irregular units, and lowest for regular units in both winter and summer females (Table 1)

(two-way ANOVA and Tukey test; effect of resting discharge type; $F=16.26$; $\mathrm{df}=2,107 ; p<0.001$ ). In addition, $\mathrm{BF}$ did not differ among the three resting discharge types (two-way ANOVA; effect of resting discharge type; $F=0.40 ; \mathrm{df}=2,107 ; p=0.67$ ). Thus, these results show that VS at BF decreases with increasing resting discharge rate and that silent units have the highest VS at BF.

\section{Discussion}

To our knowledge, this study is the first to demonstrate seasonal plasticity of peripheral auditory frequency sensitivity in a natural population of vertebrates. Our aim was to determine whether the neurophysiological response properties of the peripheral auditory system are dependent on reproductive state and whether the female midshipman auditory sense is seasonally adapted to encode conspecific vocalizations essential to successful reproduction. Our results demonstrate that most auditory units in reproductive, summer females show robust temporal encoding (as measured by spike synchronization values, VS, $\geq 0.70$ ) up to 340 $\mathrm{Hz}$, whereas nonreproductive winter females show comparable coding only up to $100 \mathrm{~Hz}$. This dramatic broadening in the encoding of behaviorally relevant frequencies among summer fish is paralleled by increases in $\mathrm{BF}, \mathrm{VS}$ at $\mathrm{BF}$, evoked spike rate at $\mathrm{BF}$, and the percentage of units that show significant VS values. In addition, changes in the resting discharge properties of auditory saccular afferents in reproductive summer females are also consistent with changes in auditory frequency sensitivity for robust encoding of frequencies $>100 \mathrm{~Hz}$.

\section{Plasticity of auditory response properties}

We show that there is a dramatic increase in BF (Fig. 4) and in the phase-locking accuracy of auditory saccular afferents to a broad range of frequencies $>100 \mathrm{~Hz}$ (Fig. 5) among female midshipman during the reproductive summer season. Fay and Ream (1986) reported in their study of goldfish that a high occurrence of silent saccular afferents was associated with relatively high BF $(>330 \mathrm{~Hz})$. Consistent with this relationship, we found an increased percentage of silent units and enhanced sensitivity at higher frequencies among summer afferents. Furthermore, the large increase in the percentage of units that showed significant VS to iso-intensity tones above $140 \mathrm{~Hz}$ during the summer indicates that reproductive females have a higher probability of encoding frequencies $>140 \mathrm{~Hz}$ than nonreproductive winter females.

We also show that VS at BF is negatively correlated with resting discharge rate and that silent units have the highest degree of 


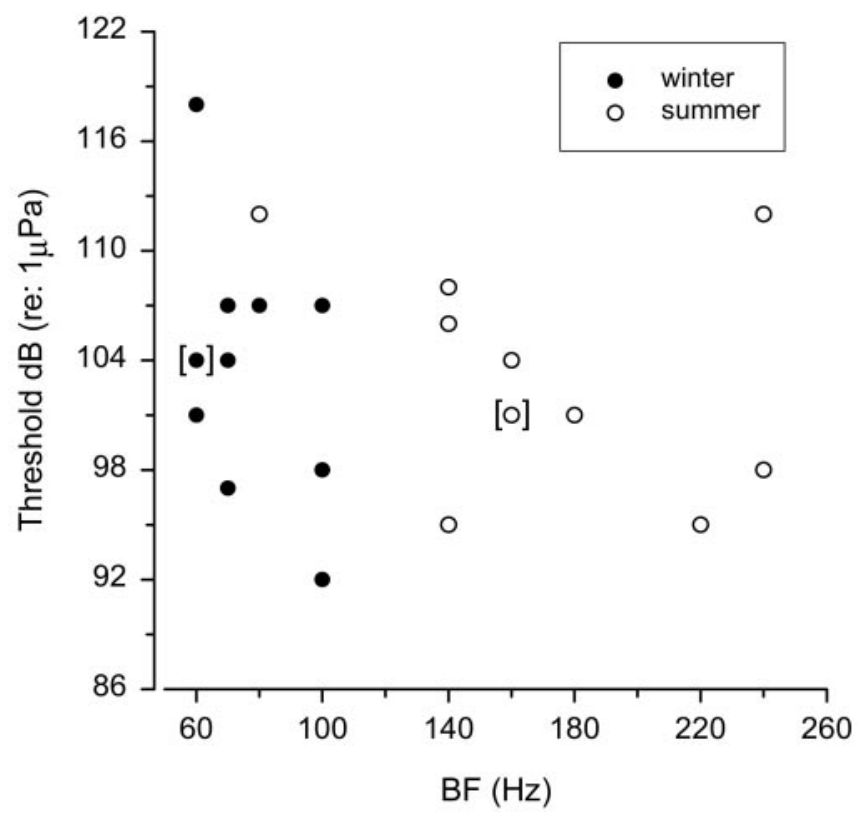

Figure 6. Relationship between auditory threshold (decibels, re $1 \mu \mathrm{Pa}$ ) and best frequency $(B F)$ of female midshipman auditory saccular afferents recorded during the winter $(\mathbf{O})$ and summer (○). Note that the brackets ([ ]) indicate the overlap of two data points.

phase locking at BF. A similar relationship of decreasing phaselocking accuracy with increasing spike rate has been identified in the response of mammalian auditory afferents to single tones (Johnson, 1980; Palmer and Russell, 1986). The increase in the number of silent units, which have the highest degree of phase locking at $\mathrm{BF}$, is consistent with a general increase in the robustness of temporal encoding by the population of saccular primary afferents in summer females.

\section{Functional significance of peripheral auditory plasticity}

The frequency sensitivity of the saccular afferents for summer females closely parallels, in particular, the fundamental frequency and the major upper harmonics of the male advertisement call (Fig. 9). We propose that this plasticity may function to increase the probability of conspecific mate detection and localization, especially in shallow water and sometimes noisy environments such as those where midshipman court and nest. Gravid females use the auditory sense to detect and locate male conspecifics that generate multiharmonic hums (Fig. 9A,B) from their nests (Ibara et al., 1983; Brantley and Bass, 1994; McKibben and Bass, 1998, 2001a). The fundamental frequency of the hum is highly stable and ranges from 90 to $100 \mathrm{~Hz}$, but most of the spectral energy of the hum is contained in upper harmonics that range up to $400 \mathrm{~Hz}$, with the second and third harmonics typically containing as much or more spectral energy as the fundamental (Fig. 9B) (Brantley and Bass, 1994; Bass et al., 1999; M. Marchaterre and A. Bass, unpublished observations). The harmonics of the hum likely increase signal (hum) detection in shallow water environments where higher harmonic frequency components are transmitted over a greater distance than the fundamental frequency because of the inverse relationship between water depth and the cutoff frequency of sound transmission (for review, see Bass and Clark, 2003) [but see Fine and Lenhardt (1983) for study in closely related sonic toadfish]. Although our results and those of McKibben and Bass (1999) show that the peripheral auditory system of midshipman is adapted to encode the fundamental frequency of the hum, the encoding of
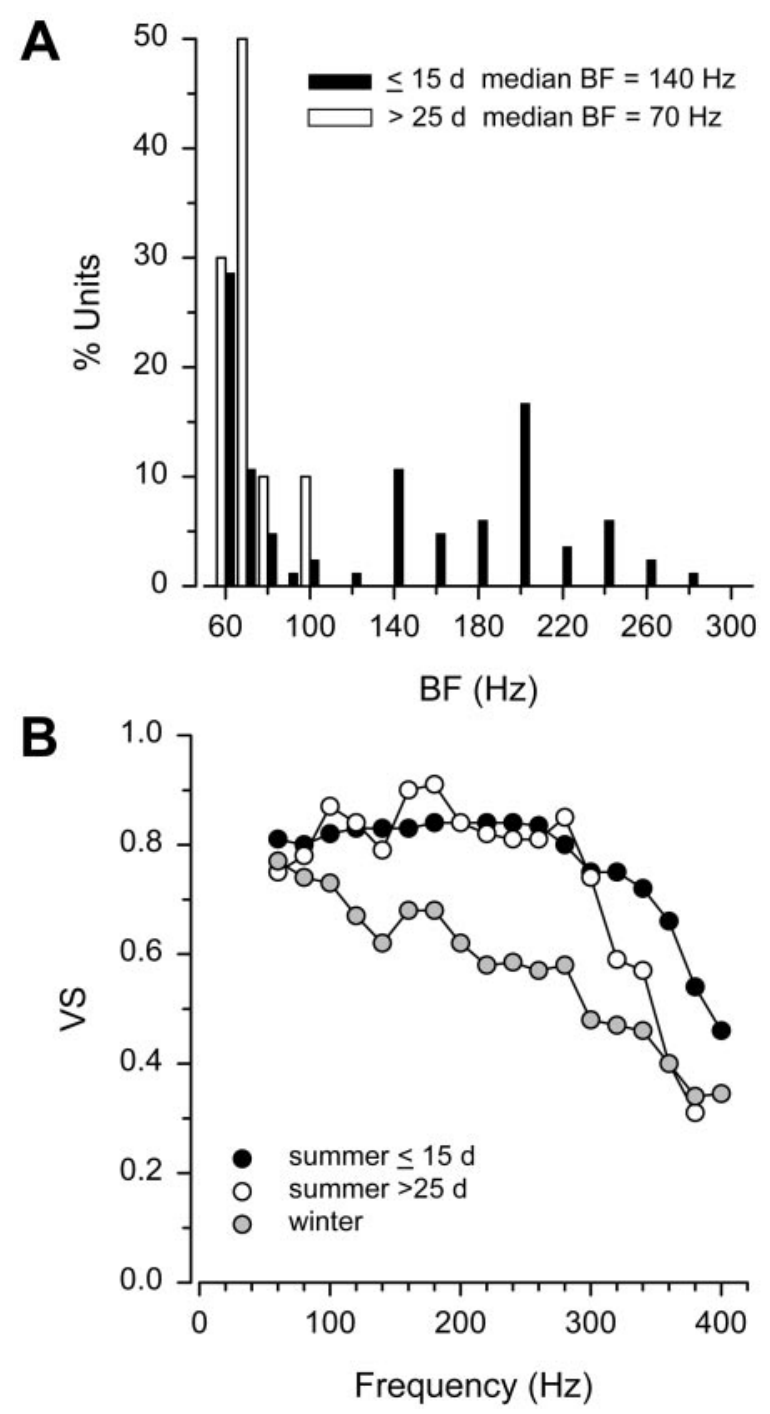

Figure 7. Frequency sensitivity of female midshipman auditory saccular afferents recorded $\leq 15$ and $>25 \mathrm{~d}$ after collection from nest during the reproductive summer season. $A$, Distribution of best frequencies $(B F)$ of saccular afferents based on the vector strength (VS) of synchronization to iso-intensity tones of $130 \mathrm{~dB}$ (re $1 \mu \mathrm{Pa}$ ). $B$, Iso-intensity curves based on vector strength (VS) of synchronization to iso-intensity tones of $130 \mathrm{~dB}$ (re $1 \mu \mathrm{Pa}$ ) that show median VS values for females recorded during the winter ( gray filled circles; from Fig. $5 A$ ) and summer that were sampled $\leq 15 \mathrm{~d}$ (black filled circles; from Fig. $5 B$ ) and $>25 \mathrm{~d}$ (white filled circles) after collection from nests.

hum-like tones by saccular afferents is enhanced when harmonics are added to tonal stimuli (McKibben and Bass, 2001b). Thus, the increased sensitivity of females to the upper harmonics during the summer may both increase the detection of vocalizations at greater distances from the nest as well as enhance the detection and encoding of the fundamental at close range.

Male midshipman also respond to playbacks of hums, although not nearly as robustly as females (McKibben and Bass, 1998). Peripheral auditory plasticity may also extend to males, thereby enhancing their detection and localization of conspecific males during, for example, the establishment of nest sites (Brantley and Bass, 1994). The frequency response properties of the peripheral auditory system in males have been characterized only for individuals held in captivity through the nonreproductive winter months, and their iso-intensity response profiles resemble those of the winter females studied here (McKibben and Bass, 


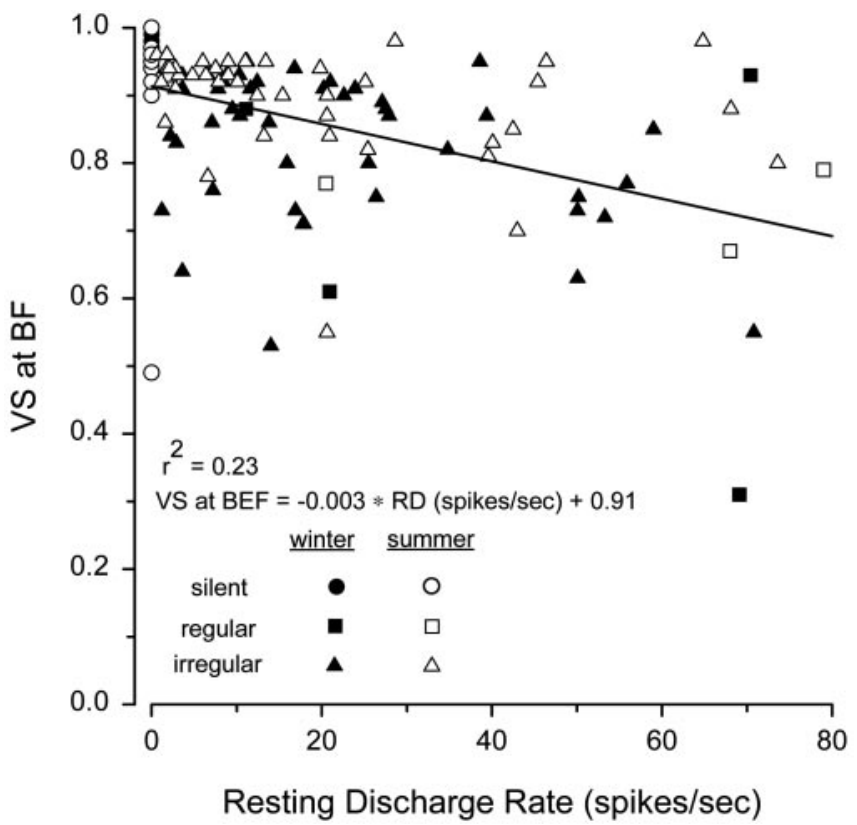

Figure 8. Relationship between vector strength (VS) of synchronization at best frequency $(B F)$ and resting discharge rate for auditory saccular afferent neurons recorded from female midshipman. VS at BF was plotted for saccular afferents on the basis of resting discharge type (i.e., silent, regular, and irregular units).

1999). Thus, future studies need to determine whether seasonal plasticity of peripheral auditory frequency sensitivity also occurs in males.

Similarly, many female anurans use male advertisement calls to recognize and locate conspecifics during the breeding season (Capranica et al., 1973; Ryan, 1985; Gerhardt, 1988). In many species, there is a close match between peripheral auditory sensitivity (BF) and the spectral peak in the male's advertisement call (Wilczynski et al., 1992, 1993). Furthermore, the match between call spectrum and peripheral frequency sensitivity extends to variance between populations and the sexes within a single species (Narins and Capranica, 1976; Keddy-Hector et al., 1992; Wilczynski et al., 1992, 1993). Divergence between populations and the sexes may yet have a seasonal component much like the one we have demonstrated in midshipman fish.

\section{Mechanisms for peripheral auditory plasticity}

The mechanism(s) responsible for the seasonal plasticity of peripheral auditory frequency sensitivity in the midshipman is unknown. One hypothesis is that midshipman auditory receptors are susceptible to entrainment by extrinsic acoustic stimuli, which in this case would include the prominent upper harmonics of male advertisement calls produced during the summer (Fig. $9 B$ ). Although a comparable hypothesis was proposed for the frequency sensitivity of tuberous electroreceptors of weakly electric fishes (Bass and Hopkins, 1984; Meyer et al., 1984), auditory entrainment in female midshipman by male hums seems less plausible. Females may spend little time in the vicinity of humming males because they move into nests on a single night, spawn within a $24 \mathrm{hr}$ period, and then leave to return to offshore sites (Hubbs, 1920; Arora, 1948; Brantley and Bass, 1994; A. Bass, personal observation).

An alternative, but not mutually exclusive, mechanism for the plasticity of frequency sensitivity in midshipman is one that is dependent on seasonal changes in circulating levels of gonadal

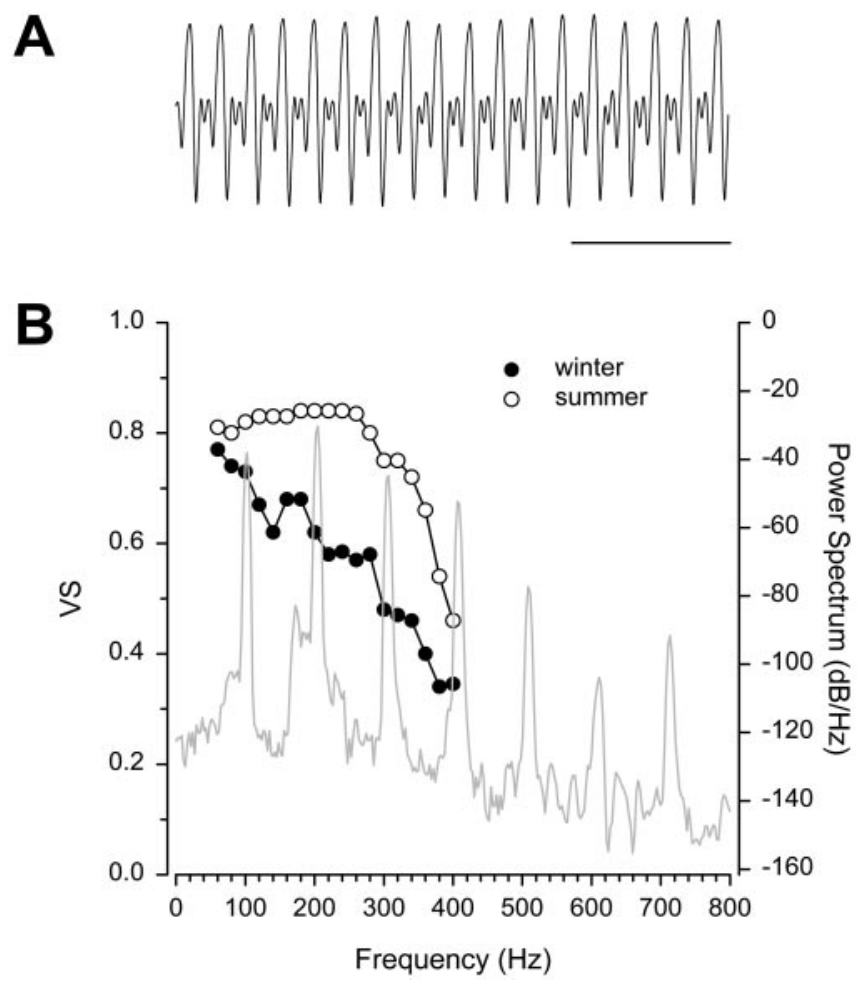

Figure 9. A, Representative example of a hum recorded at $16^{\circ} \mathrm{C}$ from a nesting type I male midshipman, P. notatus. Calibration: 50 msec. B, Match between the power spectrum of the representative hum $(A)$ and the frequency sensitivity of female auditory saccular afferent neurons recorded during the winter and summer. Iso-intensity curves are based on vector strength (VS) of synchronization to iso-intensity tones of $130 \mathrm{~dB}(\mathrm{re} 1 \mu \mathrm{Pa}$ ) and show median VS values for females recorded during the winter ( $\mathbf{O}$; from Fig. $5 A)$ and summer $(\bigcirc$; from Fig. $5 B)$.

steroids, as proposed for changes in auditory sensitivity among female humans during the menstrual cycle (for review, see McFadden, 1998). For example, Haggard and Gaston (1978) found that the accuracy of judging the octave frequency for a $203 \mathrm{~Hz}$ tone (octave matching; a frequency discrimination task) was lowest during the midluteal phase of the menstrual cycle and highest during ovulation, which is when estradiol and testosterone levels peak. Among teleost fish in general, gonadal steroid levels rise in females during ovarian recrudescence and then peak before spawning (Pankhurst and Carragher, 1991); this same pattern also occurs among female midshipman and is followed by a precipitous drop in gonadal steroid levels after spawning [J. Sisneros, P. Forlano, R. Knapp, and A. Bass, unpublished observations; also see Brantley et al. (1993) and Knapp et al. (1999) for plasma steroid levels during breeding season]. Low gonadal steroid levels after spawning may explain, in part, why reproductive stateenhanced sensitivity decreases in summer females when sampled $>25 \mathrm{~d}$ after collection from nests (Fig. 7). The time course of these events is consistent with a possible genomic effect on auditory receptors elicited via a reduction in natural circulating gonadal steroid levels. Similarly, naturally elevated levels of gonadal steroids before spawning may have a direct effect on the frequency sensitivity of auditory hair cells as proposed for the steroid-related changes in the frequency sensitivity characteristics of electroreceptors (Keller et al., 1986; Sisneros and Tricas, 2000). Among vertebrates in general, including the closely related toadfish (same Family and Order as midshipman), electrical resonance arising from the ion channel current kinetics of the basolateral membrane of the auditory hair cell is considered the major 
contributing factor for frequency sensitivity in the low-frequency range of interest here (Steinacker and Romero, 1991, 1992; Fettiplace and Fuchs, 1999). The electrical resonance is caused by the interaction between inward calcium and outward calciumdependent potassium currents that produce an electrical oscillation of the receptor potential along the receptor epithelium (Lewis and Hudspeth, 1983; Roberts et al., 1988). Thus, as proposed for electroreceptors (Zakon, 1987; Zakon et al., 1991), gonadal steroids may exert their effects on the frequency sensitivity of saccular hair cells by genomically regulating the differential transcription of ion channels that are responsible for changing the ion conductances of the receptor or, alternatively, by regulating enzymes such as protein kinases that can modulate the kinetics of existing ion channels.

Last, seasonal plasticity of peripheral auditory frequency sensitivity may also depend on changes in central input from the hindbrain efferent nucleus that directly innervates the teleostean inner ear, including that of midshipman (Bass et al., 1994). Saccular efferents provide inhibitory inputs to hair cells that can modulate their auditory sensitivity (gain) (Furukawa and Matsura, 1978; Lin and Faber, 1988). We found no difference in auditory thresholds among females in different seasonal reproductive states (Fig. 6), suggesting that peripheral auditory sensitivity is not influenced by central inputs. However, Xiao and Suga (2002) showed recently that neurons in the mammalian auditory cortex modulate the frequency sensitivity of cochlear hair cells. Thus, future studies should examine the possible seasonal effects of efferent modulation on frequency sensitivity in the midshipman peripheral auditory system.

In summary, we have shown that peripheral auditory frequency sensitivity changes with seasonal variation in the female reproductive state. We suggest that seasonal plasticity in female auditory frequency sensitivity represents an adaptation to enhance the detection of the multiharmonic advertisement calls of males that, in turn, facilitates the acquisition of auditory information needed for conspecific detection and localization. Thus, the importance of the auditory sense during breeding and associated seasonal changes in peripheral frequency sensitivity offer the midshipman auditory system as an excellent model for identifying the reproductive-related neural mechanisms responsible for auditory plasticity that may be common to all vertebrates, including humans.

\section{References}

Altermus M, Wexler BE, Boulis N (1989) Changes in perceptual asymmetry with the menstrual cycle. Neuropyschologia 2:233-240.

Arora HL (1948) Observations on the habits and early life history of the batrachoid fish, Porichthys notatus Girard. Copeia 1948:89-93.

Ball GF, Riters LV, Balthazart J (2002) Neuroendocrinology of song behavior and avian brain plasticity: multiple sites of action of sex steroid hormones. Front Neuroendocrinol 23:137-178.

Bass AH (1996) Shaping brain sexuality. Am Sci 84:352-363.

Bass AH, Clark CW (2003) The physical acoustics of underwater sound communication. In: Springer handbook of auditory research (Simmons AM, Fay RR, Popper A, eds), pp 15-64. New York: Springer.

Bass AH, Hopkins CD (1984) Shifts in frequency tuning of electroreceptors in androgen-treated mormyrid fish. J Comp Physiol [A] 155:713-724.

Bass AH, Marchaterre MA, Baker R (1994) Vocal-acoustic pathways in a teleost fish. J Neurosci 14:4025-4039.

Bass AH, Bodnar D, Marchaterre MA (1999) Complementary explanations for existing phenotypes in an acoustic communication system. In: The design of animal communication (Hauser MD, Konishi M, eds), pp 493 514. Cambridge, MA: MIT.

Batschelet E (1981) Circular statistics in biology. New York: Academic.

Bodnar DA, Bass AH (1997) Temporal coding of concurrent acoustic signals in auditory midbrain. J Neurosci 17:7553-7564.
Bodnar DA, Bass AH (1999) Midbrain combinatorial code for temporal and spectral information in concurrent acoustic signals. J Neurophysiol 81:552-563.

Brantley RK, Bass AH (1994) Alternative male spawning tactics and acoustic signals in the plainfin midshipman fish, Porichthys notatus (Teleostei, Batrachoididae). Ethology 96:213-232.

Brantley RK, Wingfield JC, Bass AH (1993) Sex steroid levels in Porichthys notatus, a fish with alternative reproductive tactics, and a review of the hormonal bases for male dimorphism among teleost fishes. Horm Behav 27:332-347.

Capranica RR, Frishkopf LS, Nevo E (1973) Encoding of geographic dialects in the auditory system of the cricket frog. Science 182:1272-1275.

Cohen MJ, Winn HE (1967) Electrophysiological observations on hearing and sound production in the fish, Porichthys notatus. J Exp Zool 165:355-370.

Fay RR (1978a) Phase-locking in goldfish saccular nerve fibers accounts for frequency discrimination capacities. Nature 275:320-322.

Fay RR (1978b) Coding of information in single auditory-nerve fibers of the goldfish. J Acoust Soc Am 63:136-146.

Fay RR (1982) Neural mechanisms of an auditory temporal discrimination by the goldfish. J Comp Physiol [A] 147:201-216.

Fay RR (1990) Suppression and excitation in auditory nerve fibers of the goldfish, Carassius auratus. Hear Res 48:93-110.

Fay RR (1994) The sense of hearing in fishes: psychophysics and neurophysiology. Sens Syst 8:262-268.

Fay RR, Ream TJ (1986) Acoustic response and tuning in saccular nerve fibers of the goldfish (Carassius auratus). J Acoust Soc Am 79:1883-1895.

Fettiplace R, Fuchs PA (1999) Mechanisms of hair cell tuning. Annu Rev Physiol 61:809-834.

Fine ML, Lenhardt ML (1983) Shallow-water propagation of the toadfish mating call. Comp Biochem Physiol [A] 76:225-231.

Furukawa T, Matsura S (1978) Adaptive rundown of excitatory postsynaptic potentials at synapses between hair cells and eighth nerve fibers in goldfish. J Physiol (Lond) 276:193-209.

Gerhardt HC (1988) Acoustical properties used in call recognition by frogs and toads. In: The evolution of the amphibian auditory system (Fritzsch B, Ryan MJ, Wilczynski W, Hetherington TE, Walkowiak W, eds), pp 455-483. New York: Wiley.

Goldberg JM, Brown PB (1969) Response of binaural neurons of dog superior olivary complex to dichotic tonal stimuli: some physiological mechanisms of sound localization. J Neurophysiol 32:613-636.

Haggard M, Gaston JB (1978) Changes in auditory perception in the menstrual cycle. Br J Audiol 12:105-118.

Hubbs CL (1920) The bionomics of Porichthys notatus Girard. Am Nat 54:380-384.

Ibara RM, Penny LT, Ebeling AW, van Dykhuizen G, Cailliet G (1983) The mating call of the plainfin midshipman fish, Porichthys notatus. In: Predators and prey in fishes (Noakes DGL, Lindquist DG, Helfman GS, Ward JA (eds), pp 205-212. The Hague, Netherlands: Junk Press.

Javel E, Mott JB (1988) Physiological and psychophysical correlates of temporal processes in hearing. Hear Res 34:275-294.

Johnson DH (1980) The relationship between spike rate and synchrony in responses of auditory-nerve fibers to single tones. J Acoust Soc Am 68:1115-1122.

Keddy-Hector AC, Wilczynski W, Ryan MJ (1992) Call patterns and basilar papilla tuning in cricket frogs. II. Intrapopulation variation and allometry. Brain Behav Evol 39:238-246.

Keller CH, Zakon HH, Sanchez DY (1986) Evidence for a direct effect of androgens on electroreceptor tuning. J Comp Physiol [A] 158:301-310.

Kelly MJ, Wagner EJ (1999) Estrogen modulation of G-protein-coupled receptors. Trends Endocrinol Metab 10:369-374.

Knapp R, Wingfield JC, Bass AH (1999) Steroid hormones and paternal care in the plainfin midshipman fish (Porichthys notatus). Horm Behav 35:81-89.

Köppl C, Manley GA (1990) Peripheral auditory processing in the bobtail lizard Tiliqua rugosa. III. Patterns of spontaneous and tone-evoked nervefiber activity. J Comp Physiol [A] 167:113-117.

Lewis ER, Hudspeth AJ (1983) Voltage-dependent and ion-dependent conductances in solitary vertebrate hair-cells. Nature 304:538-541.

Lin J-W, Faber DS (1988) An efferent inhibition of auditory afferents mediated by the goldfish Mauthner cell. Neuroscience 24:829-836.

Manley GA, Haeseler C, Brix J (1991) Innervation patterns and spontane- 
ous activity of afferent fibers to the lagenar macula and apical basilar papilla of the chick's cochlea. Hear Res 56:211-226.

McFadden D (1998) Sex differences in the auditory system. Dev Neuropsychol 14:261-298.

McKibben JR, Bass AH (1998) Behavioral assessment of acoustic parameters relevant to signal recognition and preference in a vocal fish. J Acoust Soc Am 104:3520-3533.

McKibben JR, Bass AH (1999) Peripheral encoding of behaviorally relevant acoustic signals in a vocal fish: single tones. J Comp Physiol [A] 184:563-576.

McKibben JR, Bass AH (2001a) Effects of temporal envelope modulation on acoustic signal recognition in a vocal fish, the plainfin midshipman. J Acoust Soc Am 109:2934-2943.

McKibben JR, Bass AH (2001b) Peripheral encoding of behaviorally relevant acoustic signals in a vocal fish: harmonic and beat stimuli. J Comp Physiol [A] 187:271-285.

Meyer JH, Zakon HH, Heiligenberg W (1984) Steroid influences upon the electrosensory system of weakly electric fish: direct effects upon discharge frequencies with indirect effects upon electroreceptor tuning. J Comp Physiol [A] 154:625-631.

Narins PM, Capranica RR (1976) Sexual differences in the auditory system of the tree frog, Eleutherodactylus coqui. Science 192:378-380.

Palmer AR, Russell IJ (1986) Phase-locking in the cochlear nerve of the guinea-pig and its relation to the receptor potential of inner hair-cells. Hear Res 24:1-15.

Pankhurst NW, Carragher JF (1991) Seasonal endocrine cycles in marine teleosts. In: Reproductive physiology of fish 1991 (Scott AP, Sumpter JP, Kime DE, Rolfe MS, eds), pp 131-135. Sheffield, UK: Fish Symp 91.

Roberts WM, Howard J, Hudspeth AJ (1988) Hair cells: transduction, tuning, and transmission in the inner ear. Annu Rev Cell Biol 4:63-92.
Ryan MJ (1985) The Tungara frog, a study in sexual selection and communication. Chicago: University of Chicago.

Sisneros JA, Tricas TC (2000) Androgen-induced changes in the response dynamics of ampullary electrosensory primary afferent neurons. J Neurosci 20:8586-8595.

Steinacker A, Romero A (1991) Characterization of voltage-gated calciumactivated potassium currents in toadfish saccular hair cells. Brain Res 556:22-32.

Steinacker A, Romero A (1992) Voltage-gated potassium current and resonance in the toadfish saccular hair cell. Brain Res 574:229-236.

Swanson SJ, Dengerink HA (1988) Changes in pure-tone thresholds and temporary threshold shifts as a function of menstrual cycle and oral contraceptives. J Speech Hear Res 31:569-574.

Tramontin AD, Brenowitz EA (2000) Seasonal plasticity in the adult brain. Trends Neurosci 23:251-258.

Weeg M, Fay RR, Bass AH (2002) Directionality and frequency tuning of primary saccular afferents of a vocal fish, the plainfin midshipman (Porichthys notatus). J Comp Physiol [A] 188:631-641.

Wilczynski W, Keddy-Hector AC, Ryan MJ (1992) Call patterns and basilar papilla tuning in cricket frogs. I. Differences among populations and between sexes. Brain Behav Evol 39:229-237.

Wilczynski W, McClelland BE, Rand AS (1993) Acoustic, auditory, and morphological divergence in three species of neotropical frog. J Comp Physiol [A] 172:425-438.

Xiao Z, Suga N (2002) Modulation of cochlear hair cells by the auditory cortex in the mustached bat. Nat Neurosci 5:57-63.

Zakon HH (1987) Hormone-mediated plasticity in the electrosensory system of weakly electric fish. Trends Neurosci 10:416-421.

Zakon HH, Mills AC, Ferrari MB (1991) Androgen-dependent modulation of the electrosensory and electromotor systems of a weakly electric fish. Semin Neurosci 3:449-457. 